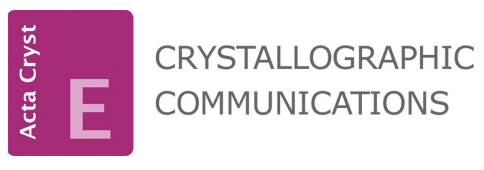

ISSN 2056-9890

Received 15 April 2020

Accepted 29 April 2020

Edited by S. Parkin, University of Kentucky, USA

Keywords: crystal structure; Cu" dimer; Schiff base ligand; 2-pyridinecarbaldehyde; methylamine.

CCDC reference: 1981381

Supporting information: this article has supporting information at journals.iucr.org/e

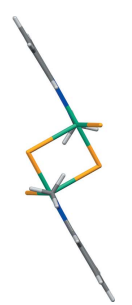

OPEN ๑ ACCESS

\section{Crystal structure and characterization of a new copper(II) chloride dimer with methyl(pyridin-2- ylmethylidene)amine}

\author{
Olga Yu. Vassilyeva, ${ }^{a *}$ Elena A. Buvaylo, ${ }^{\text {a }}$ Vladimir N. Kokozay, ${ }^{a}$ Andrii K. Melnyk ${ }^{\text {b }}$ \\ and Brian W. Skelton ${ }^{\mathrm{c}}$
}

\begin{abstract}
${ }^{a}$ Department of Chemistry, Taras Shevchenko National University of Kyiv, 64/13 Volodymyrska str., Kyiv 01601, Ukraine, bInstitute for Sorption and Problems of Endoecology, The National Academy of Sciences of Ukraine, 13 General Naumova str., Kyiv 03164, Ukraine, and ' School of Molecular Sciences, M310, University of Western Australia, Perth, WA 6009, Australia. *Correspondence e-mail: vassilyeva@univ.kiev.ua
\end{abstract}

The new copper(II) complex, namely, di- $\mu$-chlorido-bis\{chlorido[methyl(pyridin-2-ylmethylidene)amine- $\left.\left.\kappa^{2} N, N^{\prime}\right] \operatorname{copper}(\mathrm{II})\right\}, \quad\left[\mathrm{Cu}_{2} \mathrm{Cl}_{4}\left(\mathrm{C}_{7} \mathrm{H}_{8} \mathrm{~N}_{2}\right)_{2}\right], \quad(\mathrm{I})$, with the ligand 2-pyridylmethyl- $N$-methylimine ( $L$, a product of Schiff base condensation between methylamine and 2-pyridinecarbaldehyde) is built of discrete centrosymmetric dimers. The coordination about the $\mathrm{Cu}^{\mathrm{II}}$ ion can be described as distorted square pyramidal. The base of the pyramid consists of two nitrogen atoms from the bidentate chelate $L[\mathrm{Cu}-\mathrm{N}=2.0241$ (9), 2.0374 (8) $\AA$ ] and two chlorine atoms $[\mathrm{Cu}-\mathrm{Cl}=2.2500$ (3), 2.2835 (3) $\AA$ ]. The apical position is occupied by another $\mathrm{Cl}$ atom with the apical bond being significantly elongated at 2.6112 (3) $\AA$. The trans angles of the base are 155.16 (3) and 173.79 (2) $)^{\circ}$. The $\mathrm{Cu}$ ‥Cu separation in the dimer is 3.4346 (3) $\AA$. In the crystal structure, the loosely packed dimers are arranged in stacks propagating along the $a$ axis. The X-band polycrystalline $77 \mathrm{~K} \mathrm{EPR} \mathrm{spectrum} \mathrm{of} \mathrm{(I)} \mathrm{demonstrates} \mathrm{a}$ typical axial pattern characteristic of mononuclear $\mathrm{Cu}^{\mathrm{II}}$ complexes. Compound (I) is redox active and shows a cyclic voltammetric response with $E_{1 / 2}=$ $-0.037 \mathrm{~V}$ versus silver-silver chloride electrode (SSCE) assignable to the reduction peak of $\mathrm{Cu}^{\mathrm{II}} / \mathrm{Cu}^{\mathrm{I}}$ in methanol as solvent.

\section{Chemical context}

The crystal structure of the title compound was determined as part of our ongoing research focused on the design and synthesis of the organic-inorganic halometallates with substituted imidazo[1,5-a]pyridinium cations. The first cation in the series, 2-methyl-3-(pyridin-2-yl)imidazo[1,5-a]pyridinium, was obtained by the replacement of a conventional aqueous solution of methylamine with its solid hydrochloride salt in the reaction with 2-pyridinecarbaldehyde (2-PCA) in methanol (Buvaylo et al., 2015). The cation is a result of the acid-catalysed oxidative condensation-cyclization between two molecules of 2-PCA and one molecule of $\mathrm{CH}_{3} \mathrm{NH}_{2}$ with the acid added as an adduct of the amine. The prepared in situ organic cation forms a halometallate salt in the subsequent interaction with divalent metal halides $(M=\mathrm{Mn}, \mathrm{Co}, \mathrm{Zn}, \mathrm{Cd})$ or can be isolated in salt form with $\mathrm{Cl}^{-} / \mathrm{NO}_{3}{ }^{-}$anions (Buvaylo et al., 2015; Vassilyeva et al., 2019a,b, 2020).

The burgeoning research in the field of organic-inorganic halometallate-based hybrids in search of new applications (Wheaton et al., 2018; Yangui et al., 2019; Szklarz et al., 2020) prompted us to extend the developed reaction to the possible 
preparation of a mixed-metal hybrid halometallate by combining two different metals with the organic precursors:

$\mathrm{Cu}-\mathrm{NiCl}_{2} \cdot 6 \mathrm{H}_{2} \mathrm{O}-\mathrm{CH}_{3} \mathrm{NH}_{2} \cdot \mathrm{HCl}-2-\mathrm{PCA}-\mathrm{CH}_{3} \mathrm{OH}$ in air

Adhering to the direct synthesis approach (Kokozay et al., 2018), one of the metals was introduced in a zerovalent state. Our earlier studies showed that a metal powder was oxidized in solution to form a coordination compound in the presence of a proton-donating agent and dioxygen from the air, this being reduced to give $\mathrm{H}_{2} \mathrm{O}$.

Such a complication of the reaction system had an adverse effect, precluding formation of the desired heterocycle with the imidazo[1,5-a]pyridinium skeleton but afforded the Schiff base 2-pyridylmethyl- $N$-methylimine $(L)$ instead. The latter is a pale-yellow liquid usually accessible by a straightforward interaction of 2-PCA with a $40 \%$ aqueous solution of methylamine (Schulz et al., 2009). In the present work, the imine $L$ was isolated as the copper(II) complex $\left[\mathrm{CuLCl}_{2}\right]_{2}$, (I), the dimeric structure of which has been established by X-ray crystallography. The title compound was characterized by elemental analysis, IR and EPR spectroscopy as well as cyclic voltammetry.

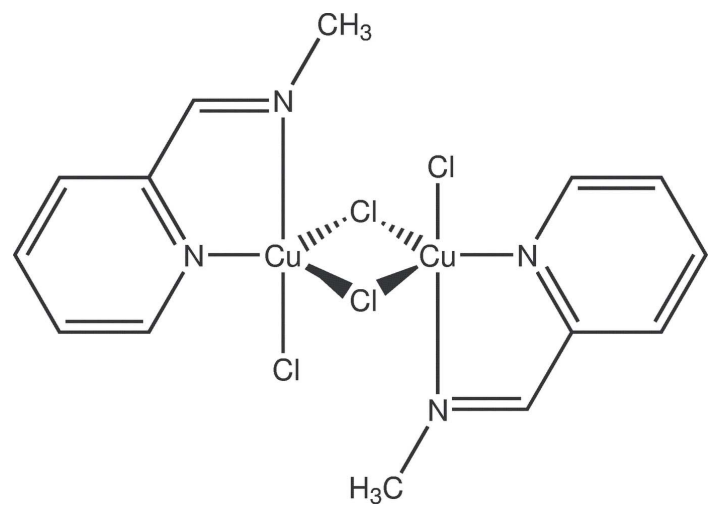

\section{Structural commentary}

The title complex crystallizes in the triclinic space group, $P \overline{1}$; the dimeric molecule is situated on a crystallographic inversion centre. The coordination about the $\mathrm{Cu}$ atom can be

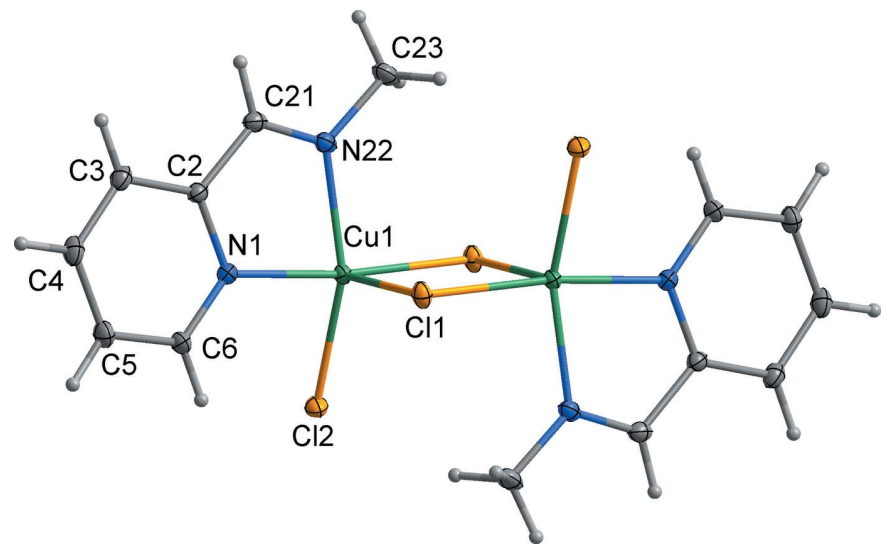

Figure 1

Molecular structure and principal labelling of $\left[\mathrm{CuLCl}_{2}\right]_{2}$ (I) with ellipsoids at the $50 \%$ probability level.
Table 1

Selected geometric parameters $\left(\AA{ }^{\circ}\right)$.

\begin{tabular}{lclc}
\hline $\mathrm{Cu} 1-\mathrm{N} 1$ & $2.0241(9)$ & $\mathrm{Cu} 1-\mathrm{Cl} 1^{\mathrm{i}}$ & $2.2835(3)$ \\
$\mathrm{Cu} 1-\mathrm{N} 22$ & $2.0374(8)$ & $\mathrm{Cu} 1-\mathrm{Cl} 1$ & $2.6112(3)$ \\
$\mathrm{Cu} 1-\mathrm{Cl} 2$ & $2.2500(3)$ & & \\
& & & \\
$\mathrm{N} 1-\mathrm{Cu} 1-\mathrm{N} 22$ & $80.20(3)$ & $\mathrm{N} 1-\mathrm{Cu} 1-\mathrm{Cl} 1$ & $88.81(3)$ \\
$\mathrm{N} 1-\mathrm{Cu} 1-\mathrm{Cl} 2$ & $92.29(2)$ & $\mathrm{N} 22-\mathrm{Cu} 1-\mathrm{Cl} 1$ & $94.79(3)$ \\
$\mathrm{N} 22-\mathrm{Cu} 1-\mathrm{Cl} 2$ & $155.16(3)$ & $\mathrm{Cl} 2-\mathrm{Cu} 1-\mathrm{Cl} 1$ & $108.803(10)$ \\
$\mathrm{N} 1-\mathrm{Cu} 1-\mathrm{Cl} 1^{\mathrm{i}}$ & $173.79(2)$ & $\mathrm{Cl} 1^{\mathrm{i}}-\mathrm{Cu} 1-\mathrm{Cl} 1$ & $91.137(10)$ \\
$\mathrm{N} 22-\mathrm{Cu} 1-\mathrm{Cl}^{\mathrm{i}}{ }^{\mathrm{i}}$ & $93.61(3)$ & $\mathrm{Cu} 1^{\mathrm{i}}-\mathrm{Cl} 1-\mathrm{Cu} 1$ & $88.864(11)$ \\
$\mathrm{Cl} 2-\mathrm{Cu} 1-\mathrm{Cl}^{\mathrm{i}}$ & $93.600(11)$ & & \\
& & &
\end{tabular}

Symmetry code: (i) $-x+1,-y+1,-z+1$.

described as distorted square pyramidal. The angular structural index parameter, $\tau=(\beta-\alpha) / 60$, evaluated from the two largest angles $(\alpha<\beta)$ in the five-coordinated geometry, which has ideal values of 1 for an equilateral bipyramid and 0 for a square pyramid, is equal to 0.31 (Table 1 ). The base of the pyramid consists of the two nitrogen atoms, N1, N22 from the bidentate chelate ligand $L$ and the two chlorine atoms, $\mathrm{Cl} 2$ and the centrosymmetrically related $\mathrm{Cl} 1$ of the dimer (Fig. 1). Bond parameters are unexceptional (Table 1). The apical position is occupied by the $\mathrm{Cl} 1$ atom with the apical bond being significantly elongated at 2.6112 (3) A compared to the $\mathrm{Cu} 1-\mathrm{Cl}^{\mathrm{i}}$ bond length of 2.2835 (3) $\AA$ [symmetry code: (i) $1-x, 1-y, 1-z]$. The trans angles of the base are N22$\mathrm{Cu} 1-\mathrm{Cl} 2=155.16(3)^{\circ}$ and $\mathrm{N} 1-\mathrm{Cu} 1-\mathrm{Cl}^{\mathrm{i}}=173.79(2)^{\circ}$. The cis angles at the copper atom vary from 80.20 (3) to $108.803(10)^{\circ}$. The $\mathrm{Cu} \cdots \mathrm{Cu}^{\mathrm{i}}$ separation in the dimer is 3.4346 (3) А.

\section{Supramolecular features}

In the crystal structure, the dimers are arranged in stacks propagating along the $a$-axis direction and demonstrate loose packing (Fig. 2). The shortest distance between the $\mathrm{Cl}$ atoms of adjacent molecules is $4.4204(5) \AA$ for $\mathrm{Cl} 2 \cdots \mathrm{Cl} 2^{\mathrm{ii}}$ [symmetry code: (ii) $1-x, 2-y, 2-z$ ] and the minimum separation between $\mathrm{Cu}$ atoms inside the stack is as long as 7.1550 (5) $\AA$ for $\mathrm{Cu} 1 \cdots \mathrm{Cu} 1^{\mathrm{iii}}$ [symmetry code: (iii) $-x, 1-y$, $1-z]$. The neighbouring pyridyl rings along the stack are
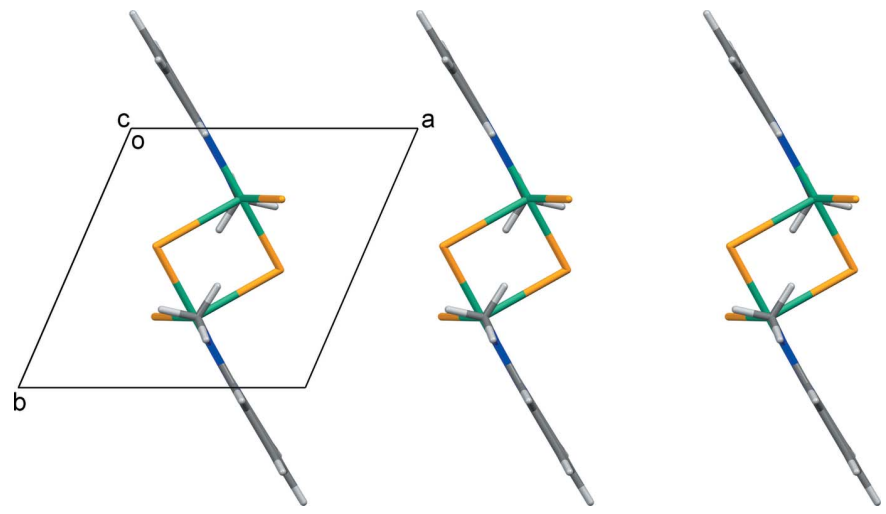

Figure 2

Fragment of crystal packing of $\left[\mathrm{CuLCl}_{2}\right]_{2}$ (I) viewed along the $c$-axis direction. 
coplanar, with the ring centroid distance being equal to the $a$ axis length [7.7054 (5) $\AA$ ], which is too great for $\pi$-overlap.

\section{Database survey}

A survey of the Cambridge Structural Database (CSD, Version 5.40, October 2019; Groom et al., 2016) reveals that crystal structures containing $L$ as a ligand comprise seven examples of divalent $\mathrm{Mn}, \mathrm{Ni}, \mathrm{Zn}$ and $\mathrm{Pd}$ as well as tetravalent Sn compounds. Among these metal complexes, the ligand demonstrates the same coordination mode as in compound (I) both in monomeric Ni [CSD refcode ADIQOV (Bai et al., 2012); NEKYOT (Pioquinto-Mendoza et al., 2013)], Zn (BULSUX; Schulz et al., 2009), Pd (NEKYUZ; PioquintoMendoza et al., 2013) and Sn coordination compounds (NELKAS and NELKEW; Guzmán-Percástegui et al., 2013) and Zn (BULSUX; Schulz et al., 2009) and Mn (VECDAJ; Bai et al., 2006) dimers. Out of all the $L$ complexes, only the nickel ones accommodate two ligands in the coordination sphere of the metal ion.

\section{IR and EPR spectroscopy measurements}

A broad band centred at about $3440 \mathrm{~cm}^{-1}$ in the IR spectrum of (I) could be due to adsorbed water molecules (see supporting information). Several bands arising above and below $3000 \mathrm{~cm}^{-1}$ are assigned to aromatic $=\mathrm{CH}$ and alkyl $\mathrm{CH}$ stretching, respectively. The characteristic $v(\mathrm{C}=\mathrm{N})$ absorption of the Schiff base, which appears at $1652 \mathrm{~cm}^{-1}$ as a sharp and rather intense band in the IR spectrum of $L$ (Schulz et al., 2009), is detected at $1648 \mathrm{~cm}^{-1}$ in the spectrum of (I). A number of sharp and intense absorptions are observed in the aromatic ring stretching $\left(1600-1400 \mathrm{~cm}^{-1}\right)$ and $\mathrm{C}-\mathrm{H}$ out-ofplane bending regions $\left(800-700 \mathrm{~cm}^{-1}\right)$.

The X-band polycrystalline EPR spectra of (I) (Fig. 3) show a typical axial pattern characteristic for the mononuclear $\mathrm{Cu}^{\mathrm{II}}$ complexes with no visible hyperfine structure. The spectra are almost temperature independent with a subtle change of their shapes seen between 295 and $77 \mathrm{~K}$. The axial symmetry characteristics of (I), $g_{\|}=2.26$ and $g_{\perp}=2.06$, with a $g_{\|}>g_{\perp}>$ 2.02 relation confirm a square-pyramidal coordination

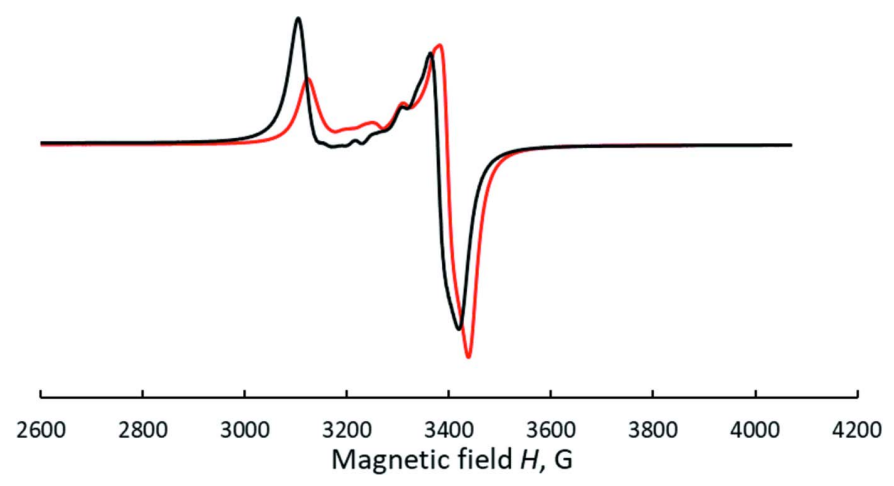

Figure 3

X-band EPR spectra of $\left[\mathrm{CuLCl}_{2}\right]_{2}$ (I) in the solid state at 293 (red) and $77 \mathrm{~K}$ (black).

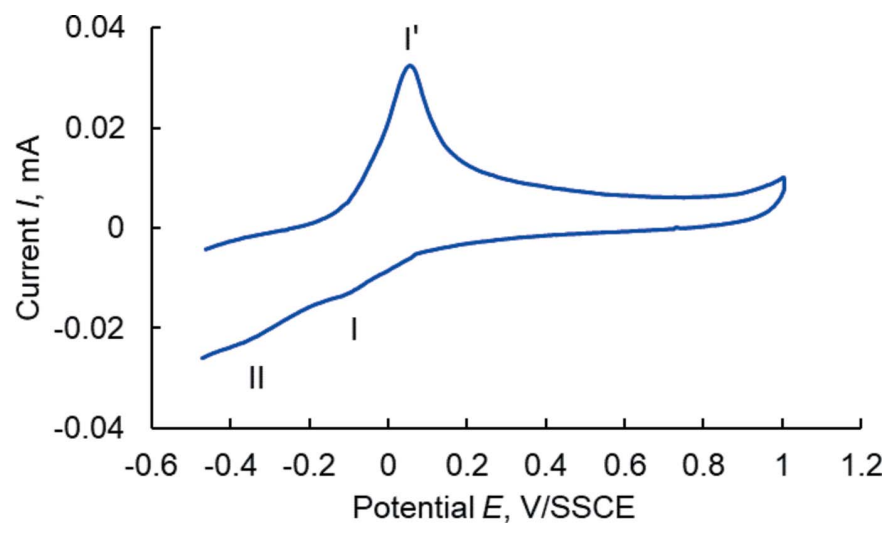

Figure 4

Cyclic voltammogram of $\left[\mathrm{CuLCl}_{2}\right]_{2}(\mathrm{I}), 0.1 \mathrm{~m} M$ in methanol mixed with $0.1 M$ acetate buffer ( $\mathrm{pH} 4)$ and $\mathrm{NaClO}_{4}$ (70:28:2) as supporting electrolyte at a glassy carbon electrode and $\mathrm{Ag} / \mathrm{AgCl}$ as reference electrode (scan rate: $100 \mathrm{mV} \mathrm{s}^{-1} ; T=298 \mathrm{~K}$ ).

geometry for the metal centre suggested by the structural data. The additional low intensity lines at $g_{\text {eff }}=2.18,2.16$ and 2.12 may indicate exchange interactions between copper(II) ions in the dimer that are probably very weak.

\section{Cyclic voltammetry}

Compound (I) is redox active and shows a cyclic voltammetric response in the potential range of $-0.12-0.047 \mathrm{~V}\left(E_{1 / 2}=\right.$ $-0.037 \mathrm{~V}$ vs SSCE), which is assignable to the reduction peak of $\mathrm{Cu}^{\mathrm{II}} / \mathrm{Cu}^{\mathrm{I}}$ (Fig. 4). The complex exhibits quasi-reversible behaviour as indicated by the non-equivalent current intensity of cathodic and anodic peaks $\left(i_{\mathrm{c}} / i_{\mathrm{a}}=0.422\right)$ and a large separation between them $(167 \mathrm{mV})$ (Crutchley et al., 1990). Since $\mathrm{Cu}^{\mathrm{I}}$ prefers to be four-coordinate, the irreversibility of the $\mathrm{Cu}^{\mathrm{II}} / \mathrm{Cu}^{\mathrm{I}}$ couple may be due to the dissociation of the dimers in solution. Reduction of copper(I) to copper(0) is associated with the irreversible peak II at $-0.36 \mathrm{~V} v s$ SSCE. The latter process causes removal of the metal centre from the complex molecule. The resulting free ligand undergoes reduction at about $-0.8 \mathrm{~V}$, which is superimposed with the reduction peak of the solvent, as is evident from the comparison between the cyclic voltammograms of (I) and supporting electrolyte methanol solutions.

\section{Synthesis and crystallization}

2-PCA $(0.19 \mathrm{ml}, 2 \mathrm{mmol})$ was magnetically stirred with $\mathrm{CH}_{3} \mathrm{NH}_{2} \cdot \mathrm{HCl}(0.27 \mathrm{~g}, 4 \mathrm{mmol})$ in $20 \mathrm{ml}$ methanol in a $50 \mathrm{ml}$ Erlenmeyer flask at room temperature (r.t.) for an hour. Dry $\mathrm{NiCl}_{2} \cdot 6 \mathrm{H}_{2} \mathrm{O}(0.23 \mathrm{~g}, 1 \mathrm{mmol})$ and $\mathrm{Cu}$ powder $(0.06 \mathrm{~g}$, $1.0 \mathrm{mmol}$ ) were added to the resulting yellow solution of the preformed Schiff base. The mixture immediately turned green and was magnetically stirred at $323 \mathrm{~K}$ in open air to achieve dissolution of the metallic copper $(4 \mathrm{~h})$. The resulting solution was filtered and left to evaporate at r.t. Green plate-like crystals of (I) suitable for X-ray analysis deposited over two days. They were filtered off, washed with diethyl ether and 
finally dried in air. Yield (based on $\mathrm{Cu}$ ): $71 \%$. Analysis calculated for $\mathrm{C}_{14} \mathrm{H}_{16} \mathrm{Cl}_{4} \mathrm{Cu}_{2} \mathrm{~N}_{4}$ (509.19): C 33.02, $\mathrm{H} \mathrm{3.17,} \mathrm{N}$ $11.00 \%$. Found: C 33.29, H 3.30, N 10.74\%. IR ( $\left.v, \mathrm{~cm}^{-1}, \mathrm{KBr}\right)$ : 3438br, 3092, 3068, 3022, 2992, 2922, 1648, 1598vs, 1568, 1474, 1434, 1364, 1300s, 1272, 1224, 1156s, 1108, 1050, 1024vs, 980, 946, 882, 782vs, 646, 514, 476, 420.

\section{Refinement}

Crystal data, data collection and structure refinement details are summarized in Table 2. Anisotropic displacement parameters were employed for the non-hydrogen atoms. All hydrogen atoms were added at calculated positions and refined by use of a riding model with isotropic displacement parameters based on those of the parent atom $(\mathrm{C}-\mathrm{H}=$ $0.95 \AA, U_{\text {iso }}(\mathrm{H})=1.2 U_{\text {eq }} \mathrm{C}$ for $\mathrm{CH}, \mathrm{C}-\mathrm{H}=0.98 \AA, U_{\text {iso }}(\mathrm{H})=$ $1.5 U_{\text {eq }} \mathrm{C}$ for $\mathrm{CH}_{3}$ ).

\section{Funding information}

Funding for this research was provided by: Ministry of Education and Science of Ukraine (project No. 19BF037-05).

\section{References}

Bai, S. Q., Fang, C. J., He, Z., Gao, E. Q., Yan, C. H. \& Hor, T. A. (2012). Dalton Trans. 41, 13379-13387.

Bai, S. Q., Gao, E. Q., He, Z., Fang, C. J., Yue, Y. F. \& Yan, C. H. (2006). Eur. J. Inorg. Chem. 2006, 407-415.

Brandenburg, K. (1999). DIAMOND. Crystal Impact GbR, Bonn, Germany.

Buvaylo, E. A., Kokozay, V. N., Linnik, R. P., Vassilyeva, O. Y. \& Skelton, B. W. (2015). Dalton Trans. 44, 13735-13744.

Crutchley, R. J., Hynes, R. \& Gabe, E. J. (1990). Inorg. Chem. 29, 4921-4928.

Farrugia, L. J. (2012). J. Appl. Cryst. 45, 849-854.

Groom, C. R., Bruno, I. J., Lightfoot, M. P. \& Ward, S. C. (2016). Acta Cryst. B72, 171-179.

Guzmán-Percástegui, E., Reyes-Mata, C. A., Martínez-Otero, D., Andrade-López, N. \& Alvarado-Rodríguez, J. G. (2013). Polyhedron, 50, 418-424.

Kokozay, V. N., Vassilyeva, O. Y. \& Makhankova, V. G. (2018). Direct Synthesis of Metal Complexes, edited by B. Kharisov, pp. 183-237. Amsterdam: Elsevier.

Macrae, C. F., Sovago, I., Cottrell, S. J., Galek, P. T. A., McCabe, P., Pidcock, E., Platings, M., Shields, G. P., Stevens, J. S., Towler, M. \& Wood, P. A. (2020). J. Appl. Cryst. 53, 226-235.

Pioquinto-Mendoza, J. R., Martínez-Otero, D., Andrade-López, N., Alvarado-Rodríguez, J. G., Salazar-Pereda, V., Sánchez-Cabrera, G. \& Zuno-Cruz, F. J. (2013). Polyhedron, 50, 289-296.
Table 2

Experimental details.

\begin{tabular}{|c|c|}
\hline \multicolumn{2}{|l|}{ Crystal data } \\
\hline Chemical formula & {$\left[\mathrm{Cu}_{2} \mathrm{Cl}_{4}\left(\mathrm{C}_{7} \mathrm{H}_{8} \mathrm{~N}_{2}\right)_{2}\right]$} \\
\hline$M_{\mathrm{r}}$ & 509.19 \\
\hline Crystal system, space group & Triclinic, $P \overline{1}$ \\
\hline Temperature $(\mathrm{K})$ & 100 \\
\hline$a, b, c(\AA)$ & $7.7054(5), 7.7240(5), 8.5606(5)$ \\
\hline$\alpha, \beta, \gamma\left({ }^{\circ}\right)$ & $103.659(5), 98.803(5), 110.273(5)$ \\
\hline$V\left(\mathrm{\AA}^{3}\right)$ & $448.74(5)$ \\
\hline$Z$ & 1 \\
\hline Radiation type & Mo $K \alpha$ \\
\hline$\mu\left(\mathrm{mm}^{-1}\right)$ & 2.97 \\
\hline Crystal size $(\mathrm{mm})$ & $0.56 \times 0.41 \times 0.16$ \\
\hline \multicolumn{2}{|l|}{ Data collection } \\
\hline Diffractometer & $\begin{array}{l}\text { Oxford Diffraction Gemini } \\
\text { diffractometer }\end{array}$ \\
\hline Absorption correction & $\begin{array}{l}\text { Analytical (CrysAlis PRO; Rigaku } \\
\text { OD, 2016) }\end{array}$ \\
\hline$T_{\min }, T_{\max }$ & $0.367,0.669$ \\
\hline $\begin{array}{l}\text { No. of measured, independent and } \\
\text { observed }[I>2 \sigma(I)] \text { reflections }\end{array}$ & $13153,4238,3866$ \\
\hline$R_{\text {int }}$ & 0.024 \\
\hline$(\sin \theta / \lambda)_{\max }\left(\AA^{-1}\right)$ & 0.827 \\
\hline \multicolumn{2}{|l|}{ Refinement } \\
\hline$R\left[F^{2}>2 \sigma\left(F^{2}\right)\right], w R\left(F^{2}\right), S$ & $0.021,0.054,1.08$ \\
\hline No. of reflections & 4238 \\
\hline No. of parameters & 111 \\
\hline $\mathrm{H}$-atom treatment & $\mathrm{H}$-atom parameters constrained \\
\hline$\Delta \rho_{\max }, \Delta \rho_{\min }\left(\mathrm{e} \AA^{-3}\right)$ & $0.68,-0.52$ \\
\hline
\end{tabular}

Computer programs: CrysAlis PRO (Rigaku OD, 2016), SHELXT (Sheldrick, 2015a), SHELXL2017 (Sheldrick, 2015b), DIAMOND (Brandenburg, 1999), Mercury (Macrae, 2020) and WinGX (Farrugia, 2012).

Rigaku OD (2016). CrysAlis PRO. Rigaku Oxford Diffraction Ltd, Yarnton, England.

Schulz, M., Klopfleisch, M., Görls, H., Kahnes, M. \& Westerhausen, M. (2009). Inorg. Chim. Acta, 362, 4706-4712.

Sheldrick, G. M. (2015a). Acta Cryst. A71, 3-8.

Sheldrick, G. M. (2015b). Acta Cryst. C71, 3-8.

Szklarz, P., Jakubas, R., Gągor, A., Bator, G., Cichos, J. \& Karbowiak, M. (2020). Inorg. Chem. Front. 7, 1780-1789.

Vassilyeva, O. Y., Buvaylo, E. A., Kokozay, V. N., Petrusenko, S. R., Melnyk, A. K. \& Skelton, B. W. (2020). Acta Cryst. E76, 309-313.

Vassilyeva, O. Y., Buvaylo, E. A., Kokozay, V. N., Skelton, B. W. \& Sobolev, A. N. (2019b). Acta Cryst. E75, 1209-1214.

Vassilyeva, O. Yu., Buvaylo, E. A., Kokozay, V. N., Skelton, B. W., Rajnák, C., Titiš, Y. \& Boča, R. (2019a). Dalton Trans. 48, 1127811284.

Wheaton, A. M., Streep, M. E., Ohlhaver, C. M., Nicholas, A. D., Barnes, F. H., Patterson, H. H. \& Pike, R. D. (2018). ACS Omega, 3, 15281-15292.

Yangui, A., Roccanova, R., McWhorter, T. M., Wu, Y., Du, M. H. \& Saparov, B. (2019). Chem. Mater. 31, 2983-2991. 


\section{supporting information}

Acta Cryst. (2020). E76, 790-793 [https://doi.org/10.1107/S2056989020005903]

\section{Crystal structure and characterization of a new copper(II) chloride dimer with methyl(pyridin-2-ylmethylidene)amine}

Olga Yu. Vassilyeva, Elena A. Buvaylo, Vladimir N. Kokozay, Andrii K. Melnyk and Brian W. Skelton

Computing details

Data collection: CrysAlis PRO (Rigaku OD, 2016); cell refinement: CrysAlis PRO (Rigaku OD, 2016); data reduction: CrysAlis PRO (Rigaku OD, 2016); program(s) used to solve structure: SHELXT (Sheldrick, 2015a); program(s) used to refine structure: SHELXL2017 (Sheldrick, 2015b); molecular graphics: DIAMOND (Brandenburg, 1999), Mercury

(Macrae, 2020); software used to prepare material for publication: WinGX (Farrugia, 2012).

Di- $\mu$-chlorido-bis $\left\{\right.$ chlorido [methyl(pyridin-2-ylmethylidene)amine- $\left.\kappa^{2} N, N^{\prime}\right] \operatorname{copper(II)\} }$

Crystal data

$\left[\mathrm{Cu}_{2} \mathrm{Cl}_{4}\left(\mathrm{C}_{7} \mathrm{H}_{8} \mathrm{~N}_{2}\right)_{2}\right]$

$M_{r}=509.19$

Triclinic, $P \overline{1}$

Hall symbol: -P 1

$a=7.7054(5) \AA$

$b=7.7240(5) \AA$

$c=8.5606(5) \AA$

$\alpha=103.659(5)^{\circ}$

$\beta=98.803(5)^{\circ}$

$\gamma=110.273(5)^{\circ}$

$V=448.74(5) \AA^{3}$

Data collection

Oxford Diffraction Gemini diffractometer

Graphite monochromator

Detector resolution: 10.4738 pixels $\mathrm{mm}^{-1}$

$\omega$ scans

Absorption correction: analytical

(CrysAlis Pro; Rigaku OD, 2016)

$T_{\min }=0.367, T_{\max }=0.669$

Refinement

Refinement on $F^{2}$

Least-squares matrix: full

$R\left[F^{2}>2 \sigma\left(F^{2}\right)\right]=0.021$

$w R\left(F^{2}\right)=0.054$

$S=1.08$

4238 reflections

$$
Z=1
$$

$F(000)=254$

$D_{\mathrm{x}}=1.884 \mathrm{Mg} \mathrm{m}^{-3}$

Mo $K \alpha$ radiation, $\lambda=0.71073 \AA$

Cell parameters from 7922 reflections

$\theta=4.0-37.5^{\circ}$

$\mu=2.97 \mathrm{~mm}^{-1}$

$T=100 \mathrm{~K}$

Plate, green

$0.56 \times 0.41 \times 0.16 \mathrm{~mm}$

13153 measured reflections

4238 independent reflections

3866 reflections with $I>2 \sigma(I)$

$R_{\text {int }}=0.024$

$\theta_{\text {max }}=36.0^{\circ}, \theta_{\text {min }}=4.2^{\circ}$

$h=-12 \rightarrow 12$

$k=-12 \rightarrow 12$

$l=-14 \rightarrow 14$

111 parameters

0 restraints

Hydrogen site location: inferred from neighbouring sites

$\mathrm{H}$-atom parameters constrained 
$w=1 /\left[\sigma^{2}\left(F_{\mathrm{o}}^{2}\right)+(0.0232 P)^{2}+0.1399 P\right]$

where $P=\left(F_{\mathrm{o}}^{2}+2 F_{\mathrm{c}}^{2}\right) / 3$

$(\Delta / \sigma)_{\max }=0.002$

$\Delta \rho_{\max }=0.68$ e $\AA^{-3}$

$\Delta \rho_{\min }=-0.52$ e $\AA^{-3}$
Extinction correction: SHELXL-2017/1

(Sheldrick 2015b),

$\mathrm{Fc}^{*}=\mathrm{kFc}\left[1+0.001 \times \mathrm{xc}^{2} \lambda^{3} / \sin (2 \theta)\right]^{-1 / 4}$

Extinction coefficient: 0.018 (2)

Special details

Geometry. All esds (except the esd in the dihedral angle between two 1.s. planes) are estimated using the full covariance matrix. The cell esds are taken into account individually in the estimation of esds in distances, angles and torsion angles; correlations between esds in cell parameters are only used when they are defined by crystal symmetry. An approximate (isotropic) treatment of cell esds is used for estimating esds involving l.s. planes.

Refinement. One low theta reflection was omitted from the refinement.

Fractional atomic coordinates and isotropic or equivalent isotropic displacement parameters $\left(\hat{A}^{2}\right)$

\begin{tabular}{lllll}
\hline & $x$ & $y$ & $z$ & $U_{\text {iso }} / U_{\text {eq }}$ \\
\hline $\mathrm{Cu} 1$ & $0.50923(2)$ & $0.72999(2)$ & $0.57914(2)$ & $0.01020(4)$ \\
$\mathrm{C} 1$ & $0.73459(3)$ & $0.54548(3)$ & $0.59992(3)$ & $0.01344(5)$ \\
$\mathrm{Cl} 2$ & $0.36774(3)$ & $0.72631(3)$ & $0.79030(3)$ & $0.01500(5)$ \\
$\mathrm{N} 1$ & $0.73406(12)$ & $0.98020(12)$ & $0.71584(10)$ & $0.01113(13)$ \\
$\mathrm{C} 2$ & $0.82713(14)$ & $1.08198(14)$ & $0.62321(12)$ & $0.01197(15)$ \\
$\mathrm{C} 21$ & $0.74454(15)$ & $0.99108(15)$ & $0.44328(12)$ & $0.01362(16)$ \\
$\mathrm{H} 21$ & 0.797176 & 1.050864 & 0.36667 & $0.016^{*}$ \\
$\mathrm{~N} 22$ & $0.59926(13)$ & $0.82859(13)$ & $0.39284(10)$ & $0.01293(14)$ \\
$\mathrm{C} 23$ & $0.51841(17)$ & $0.72996(17)$ & $0.21469(12)$ & $0.01786(18)$ \\
$\mathrm{H} 23 \mathrm{~A}$ & 0.580724 & 0.81486 & 0.153155 & $0.027^{*}$ \\
$\mathrm{H} 23 \mathrm{~B}$ & 0.380672 & 0.699047 & 0.18678 & $0.027^{*}$ \\
$\mathrm{H} 23 \mathrm{C}$ & 0.539512 & 0.609696 & 0.184401 & $0.027^{*}$ \\
$\mathrm{C} 3$ & $0.98700(15)$ & $1.25492(15)$ & $0.69291(13)$ & $0.01513(17)$ \\
$\mathrm{H} 3$ & 1.047781 & 1.324625 & 0.625083 & $0.018^{*}$ \\
$\mathrm{C} 4$ & $1.05621(15)$ & $1.32381(15)$ & $0.86576(14)$ & $0.01670(18)$ \\
$\mathrm{H} 4$ & 1.166445 & 1.441282 & 0.917816 & $0.02^{*}$ \\
$\mathrm{C} 5$ & $0.96252(15)$ & $1.21913(15)$ & $0.96081(13)$ & $0.01547(17)$ \\
$\mathrm{H} 5$ & 1.008301 & 1.263236 & 1.078576 & $0.019^{*}$ \\
$\mathrm{C} 6$ & $0.79997(14)$ & $1.04805(14)$ & $0.88085(12)$ & $0.01344(16)$ \\
$\mathrm{H} 6$ & 0.734271 & 0.977774 & 0.946118 & $0.016^{*}$ \\
\end{tabular}

Atomic displacement parameters $\left(\AA^{2}\right)$

\begin{tabular}{lllllll}
\hline & $U^{11}$ & $U^{22}$ & $U^{33}$ & $U^{12}$ & $U^{13}$ & $U^{23}$ \\
\hline $\mathrm{Cu} 1$ & $0.01109(6)$ & $0.00923(6)$ & $0.00822(5)$ & $0.00253(4)$ & $0.00183(4)$ & $0.00182(4)$ \\
$\mathrm{C} 11$ & $0.01209(9)$ & $0.01174(9)$ & $0.01270(9)$ & $0.00393(7)$ & $-0.00076(7)$ & $0.00086(7)$ \\
$\mathrm{C} 2$ & $0.01607(10)$ & $0.01358(10)$ & $0.01276(9)$ & $0.00224(8)$ & $0.00631(8)$ & $0.00342(7)$ \\
$\mathrm{N} 1$ & $0.0127(3)$ & $0.0098(3)$ & $0.0105(3)$ & $0.0037(3)$ & $0.0030(3)$ & $0.0034(2)$ \\
$\mathrm{C} 2$ & $0.0132(4)$ & $0.0110(4)$ & $0.0128(4)$ & $0.0046(3)$ & $0.0050(3)$ & $0.0049(3)$ \\
$\mathrm{C} 21$ & $0.0170(4)$ & $0.0150(4)$ & $0.0125(4)$ & $0.0082(3)$ & $0.0061(3)$ & $0.0065(3)$ \\
$\mathrm{N} 22$ & $0.0162(4)$ & $0.0142(4)$ & $0.0094(3)$ & $0.0075(3)$ & $0.0029(3)$ & $0.0037(3)$ \\
$\mathrm{C} 23$ & $0.0238(5)$ & $0.0209(5)$ & $0.0087(4)$ & $0.0100(4)$ & $0.0027(3)$ & $0.0037(3)$ \\
$\mathrm{C} 3$ & $0.0143(4)$ & $0.0118(4)$ & $0.0188(4)$ & $0.0034(3)$ & $0.0063(3)$ & $0.0052(3)$
\end{tabular}




\begin{tabular}{lllllll} 
C4 & $0.0136(4)$ & $0.0119(4)$ & $0.0200(4)$ & $0.0021(3)$ & $0.0033(3)$ & $0.0020(3)$ \\
C5 & $0.0149(4)$ & $0.0130(4)$ & $0.0135(4)$ & $0.0032(3)$ & $0.0008(3)$ & $0.0009(3)$ \\
C6 & $0.0148(4)$ & $0.0120(4)$ & $0.0102(3)$ & $0.0029(3)$ & $0.0015(3)$ & $0.0024(3)$ \\
\hline
\end{tabular}

Geometric parameters $\left(A,{ }^{\circ}\right)$

\begin{tabular}{|c|c|c|c|}
\hline $\mathrm{Cu} 1-\mathrm{N} 1$ & $2.0241(9)$ & $\mathrm{N} 22-\mathrm{C} 23$ & $1.4580(13)$ \\
\hline $\mathrm{Cu} 1-\mathrm{N} 22$ & $2.0374(8)$ & $\mathrm{C} 23-\mathrm{H} 23 \mathrm{~A}$ & 0.98 \\
\hline $\mathrm{Cu} 1-\mathrm{Cl} 2$ & $2.2500(3)$ & $\mathrm{C} 23-\mathrm{H} 23 \mathrm{~B}$ & 0.98 \\
\hline $\mathrm{Cu} 1-\mathrm{Cl1}^{\mathrm{i}}$ & $2.2835(3)$ & $\mathrm{C} 23-\mathrm{H} 23 \mathrm{C}$ & 0.98 \\
\hline $\mathrm{Cu} 1-\mathrm{Cl1}$ & $2.6112(3)$ & $\mathrm{C} 3-\mathrm{C} 4$ & $1.3953(15)$ \\
\hline $\mathrm{N} 1-\mathrm{C} 6$ & $1.3320(12)$ & $\mathrm{C} 3-\mathrm{H} 3$ & 0.95 \\
\hline $\mathrm{N} 1-\mathrm{C} 2$ & $1.3561(12)$ & $\mathrm{C} 4-\mathrm{C} 5$ & $1.3867(15)$ \\
\hline $\mathrm{C} 2-\mathrm{C} 3$ & $1.3842(14)$ & $\mathrm{C} 4-\mathrm{H} 4$ & 0.95 \\
\hline $\mathrm{C} 2-\mathrm{C} 21$ & $1.4663(14)$ & $\mathrm{C} 5-\mathrm{C} 6$ & $1.3953(14)$ \\
\hline $\mathrm{C} 21-\mathrm{N} 22$ & $1.2796(13)$ & $\mathrm{C} 5-\mathrm{H} 5$ & 0.95 \\
\hline $\mathrm{C} 21-\mathrm{H} 21$ & 0.95 & $\mathrm{C} 6-\mathrm{H} 6$ & 0.95 \\
\hline $\mathrm{N} 1-\mathrm{Cu} 1-\mathrm{N} 22$ & $80.20(3)$ & $\mathrm{C} 21-\mathrm{N} 22-\mathrm{Cu} 1$ & $114.21(7)$ \\
\hline $\mathrm{N} 1-\mathrm{Cu} 1-\mathrm{Cl} 2$ & $92.29(2)$ & $\mathrm{C} 23-\mathrm{N} 22-\mathrm{Cu} 1$ & $126.45(7)$ \\
\hline $\mathrm{N} 22-\mathrm{Cu} 1-\mathrm{Cl} 2$ & $155.16(3)$ & $\mathrm{N} 22-\mathrm{C} 23-\mathrm{H} 23 \mathrm{~A}$ & 109.5 \\
\hline $\mathrm{N} 1-\mathrm{Cu} 1-\mathrm{Cl} 1^{\mathrm{i}}$ & $173.79(2)$ & $\mathrm{N} 22-\mathrm{C} 23-\mathrm{H} 23 \mathrm{~B}$ & 109.5 \\
\hline $\mathrm{N} 22-\mathrm{Cu} 1-\mathrm{Cl}^{\mathrm{i}}$ & $93.61(3)$ & $\mathrm{H} 23 \mathrm{~A}-\mathrm{C} 23-\mathrm{H} 23 \mathrm{~B}$ & 109.5 \\
\hline $\mathrm{Cl} 2-\mathrm{Cu} 1-\mathrm{Cl}^{\mathrm{i}}$ & $93.600(11)$ & $\mathrm{N} 22-\mathrm{C} 23-\mathrm{H} 23 \mathrm{C}$ & 109.5 \\
\hline $\mathrm{N} 1-\mathrm{Cu} 1-\mathrm{C} 11$ & $88.81(3)$ & $\mathrm{H} 23 \mathrm{~A}-\mathrm{C} 23-\mathrm{H} 23 \mathrm{C}$ & 109.5 \\
\hline $\mathrm{N} 22-\mathrm{Cu} 1-\mathrm{Cl1}$ & $94.79(3)$ & $\mathrm{H} 23 \mathrm{~B}-\mathrm{C} 23-\mathrm{H} 23 \mathrm{C}$ & 109.5 \\
\hline $\mathrm{Cl} 2-\mathrm{Cu} 1-\mathrm{Cl} 1$ & $108.803(10)$ & $\mathrm{C} 2-\mathrm{C} 3-\mathrm{C} 4$ & $118.02(9)$ \\
\hline $\mathrm{Cl1}-\mathrm{Cu} 1-\mathrm{Cl1}$ & $91.137(10)$ & $\mathrm{C} 2-\mathrm{C} 3-\mathrm{H} 3$ & 121 \\
\hline $\mathrm{Cu} 1-\mathrm{C} 11-\mathrm{Cu} 1$ & $88.864(11)$ & $\mathrm{C} 4-\mathrm{C} 3-\mathrm{H} 3$ & 121 \\
\hline $\mathrm{C} 6-\mathrm{N} 1-\mathrm{C} 2$ & $118.79(8)$ & $\mathrm{C} 5-\mathrm{C} 4-\mathrm{C} 3$ & $119.36(9)$ \\
\hline $\mathrm{C} 6-\mathrm{N} 1-\mathrm{Cu} 1$ & $127.36(7)$ & $\mathrm{C} 5-\mathrm{C} 4-\mathrm{H} 4$ & 120.3 \\
\hline $\mathrm{C} 2-\mathrm{N} 1-\mathrm{Cu} 1$ & $113.81(6)$ & $\mathrm{C} 3-\mathrm{C} 4-\mathrm{H} 4$ & 120.3 \\
\hline $\mathrm{N} 1-\mathrm{C} 2-\mathrm{C} 3$ & $122.78(9)$ & $\mathrm{C} 4-\mathrm{C} 5-\mathrm{C} 6$ & $118.99(10)$ \\
\hline $\mathrm{N} 1-\mathrm{C} 2-\mathrm{C} 21$ & $113.95(8)$ & $\mathrm{C} 4-\mathrm{C} 5-\mathrm{H} 5$ & 120.5 \\
\hline $\mathrm{C} 3-\mathrm{C} 2-\mathrm{C} 21$ & $123.26(9)$ & $\mathrm{C} 6-\mathrm{C} 5-\mathrm{H} 5$ & 120.5 \\
\hline $\mathrm{N} 22-\mathrm{C} 21-\mathrm{C} 2$ & $117.82(8)$ & $\mathrm{N} 1-\mathrm{C} 6-\mathrm{C} 5$ & $122.05(9)$ \\
\hline $\mathrm{N} 22-\mathrm{C} 21-\mathrm{H} 21$ & 121.1 & $\mathrm{~N} 1-\mathrm{C} 6-\mathrm{H} 6$ & 119 \\
\hline $\mathrm{C} 2-\mathrm{C} 21-\mathrm{H} 21$ & 121.1 & $\mathrm{C} 5-\mathrm{C} 6-\mathrm{H} 6$ & 119 \\
\hline $\mathrm{C} 21-\mathrm{N} 22-\mathrm{C} 23$ & $119.31(9)$ & & \\
\hline $\mathrm{C} 6-\mathrm{N} 1-\mathrm{C} 2-\mathrm{C} 3$ & $-0.69(15)$ & $\mathrm{N} 1-\mathrm{C} 2-\mathrm{C} 3-\mathrm{C} 4$ & $1.35(16)$ \\
\hline $\mathrm{Cu} 1-\mathrm{N} 1-\mathrm{C} 2-\mathrm{C} 3$ & $-178.63(8)$ & $\mathrm{C} 21-\mathrm{C} 2-\mathrm{C} 3-\mathrm{C} 4$ & $-177.87(10)$ \\
\hline $\mathrm{C} 6-\mathrm{N} 1-\mathrm{C} 2-\mathrm{C} 21$ & $178.59(9)$ & $\mathrm{C} 2-\mathrm{C} 3-\mathrm{C} 4-\mathrm{C} 5$ & $-0.67(16)$ \\
\hline $\mathrm{Cu} 1-\mathrm{N} 1-\mathrm{C} 2-\mathrm{C} 21$ & $0.66(11)$ & $\mathrm{C} 3-\mathrm{C} 4-\mathrm{C} 5-\mathrm{C} 6$ & $-0.57(17)$ \\
\hline $\mathrm{N} 1-\mathrm{C} 2-\mathrm{C} 21-\mathrm{N} 22$ & $-0.97(14)$ & $\mathrm{C} 2-\mathrm{N} 1-\mathrm{C} 6-\mathrm{C} 5$ & $-0.66(15)$ \\
\hline $\mathrm{C} 3-\mathrm{C} 2-\mathrm{C} 21-\mathrm{N} 22$ & $178.31(10)$ & $\mathrm{Cu} 1-\mathrm{N} 1-\mathrm{C} 6-\mathrm{C} 5$ & $176.97(8)$ \\
\hline
\end{tabular}


$\mathrm{C} 2-\mathrm{C} 21-\mathrm{N} 22-\mathrm{C} 23$

$\mathrm{C} 2-\mathrm{C} 21-\mathrm{N} 22-\mathrm{Cu} 1$

Symmetry code: (i) $-x+1,-y+1,-z+1$.

Hydrogen-bond geometry $\left(A,{ }^{\circ}\right)$

$D-\mathrm{H} \cdots A$

$\mathrm{C} 6-\mathrm{H} 6 \cdots \mathrm{Cl} 2$
$-177.41(9)$

$0.77(12)$
$\mathrm{C} 4-\mathrm{C} 5-\mathrm{C} 6-\mathrm{N} 1$

$1.29(17)$

$D-\mathrm{H}$

$\mathrm{H} \cdots A$

$D \cdots A$

$D-\mathrm{H} \cdots A$

0.95

2.71

$3.2301(10)$

115 